Amirbek A.A. ${ }^{1}$, Anuarbekuly A. ${ }^{2}$, Makhanov K. ${ }^{3}$, Anlamassova M. ${ }^{4}$

$\mathrm{PhD}$, Scientific Researcher, Ankara Hacı Bayram Veli University.

${ }^{2} \mathrm{PhD}$ Student, Division of Public Administration, Ankara Hacı Bayram Veli University.

${ }^{3} \mathrm{MA}$, Research Fellow, Eurasian Research Institute.

${ }^{4} \mathrm{PhD}$, Acting Associate Professor, Khoja Akhmet Yassawi International Kazakh-Turkish University

\title{
UN POPULATION PROSPECTS: CASE OF CENTRAL ASİA
}

\section{Abstract}

The world's population is expected to increase by 2 billion people within the next 30 years, from current 7.7 billion to 9.7 billion in 2050. By 2050, the population of Central Asia is expected to grow by $36.9 \%$, which is faster than the world average of $26.2 \%$, crossing benchmark of 100 million people. Under conditions of UN demographic projections, Kazakhstan would need to maintain its yearly real GDP growth between $4.3 \%$ and $4.7 \%$ throughout 20202050 in order to maintain its current level of welfare relative to the rest of the world. Kazakhstan, as well as the entire region of Central Asia, has a demographic profile that is very favorable for having economic growth within the next three decades.

Keywords: Central Asia, GDP, United Nations, Kazakhstan, population.

А.А. Амирбек ${ }^{1}$, А.Ануарбекұлы ${ }^{2}$, Қ.Маханов $^{3}$, М.Анламасова $^{4}$

${ }^{1} \mathrm{PhD}$, Ғылыми зерттеуші, Анкара Хаджы Байрам Вели университеті.

${ }^{2} \mathrm{PhD}$ докторанты, Мемлекеттік басқару мамандығы, Анкара Хаджы Байрам Вели университеті.

${ }^{3}$ Магистр, Ғылыми қызметкер, Еуразия ғылыми-зерттеу институты.

${ }^{4}$ PhD, доцент м.а., Қ.А. Ясауи атындавы Хальққаралық қ̧азақ-түрік университеті.

\section{БҰҰ-НЫН ДЕМОГРАФИЯЛЫК БОЛЖАМДАРЫ: ОРТАЛЫК АЗИЯ МЫСАЛЫ}

Аңдатпа

Дүниежүзіндегі демографиялық жағдай алдымыздағы 30 жылда күрт өзгеріп, адамдардың саны 2 миллиардқа дейін өседі деп болжануда. 2050 жылы әлемдегі тұрғындардың жалпы саны қазіргі 7,7 миллиардтан 9,7 миллиардқа дейін көбейеді деп күтілуде. 2050 жылға дейін Орталық Азиядағы халықтың саны 36,9\% көбейіп, 100 миллионнан асуы мүмкін деп болжануда. БҰҰ-ның болжамдарына сәйкес Қазақстан Республикасы қазіргі экономикалық даму үдерісін сақтап қалуы үшін 2020-2050 жылдарында ЖІӨ-нің жыл сайынғы өсуін 4,3\%-4,7\% төмен түсірмеуі тиіс. Қысқасы Қазақстан Республикасы 2050 жылға дейін экономикалық тұрғыдан одан әрі дамуы үшін қолайлы демографиялық жағдайға ие.

Түйін сөздер: Орталық Азия, ЖІӨ, БҰҰ, Қазақстан Республикасы, демография.

Амирбек А.А. ${ }^{1}$, Ануарбекулы А. ${ }^{2}$, Маханов К. ${ }^{3}$, Анламасова M. ${ }^{4}$

${ }^{1} \mathrm{PhD}$, научный исследователь, Анкара Хаджы Байрам Вели университет

${ }^{2}$ Докторант $\mathrm{PhD}$, Специальность «Государственное управление»,

Университет имени Анкара Хаджы Байрам Вели

${ }^{3}$ Магистр, Научный сотрудник, Евразийский научно-исследовательский институт. 
§hD, и.о. доцент, Международный казахско-туреикий университет имени Ходжи Ахмеда Ясави

\section{ДЕМОГРАФИЧЕСКИЕ ПРОГНОЗЫ ООН: НА ПРИМЕРЕ ЦЕНТРАЛЬНОЙ АЗИИ}

\section{Аннотация}

Население земли по прогнозам увеличится на 2 миллиарда человек в течение следующих 30 лет, с нынешнего 7,7 миллиарда до 9,7 миллиарда в 2050 году. К 2050 году население Центральной Азии, как ожидается, вырастет на 36,9\%, превысив отметку в 100 млн. человек. В соответствии с демографи-ческими прогнозами ООН, Казахстан чтобы сохранить свой нынешний уровень благосостояния должен будет поддерживать ежегодный реальный рост ВВП в пределах 4,3\%-4,7\% в течение 2020-2050 годов. Вкратце Казахстан имеет благоприятный демографический профиль для экономического роста в ближай-шие три десятилетия.

Ключевые слова: Центральная Азия, ВВП, ООН, Республика Казахстан, демография.

According to the UN World Population Prospects report published on 17th of June of 2019 , the world's population is expected to increase by 2 billion people within the next 30 years, from current 7.7 billion to 9.7 billion in 2050. By the end of the 21st century, the world population is likely to reach its peak at about 11 billion people. As it was expected, projections show that along with the growth of the total size of the population there are very dynamic processes going on that bring important changes into the structure of the population.

One of the most obvious changes and important processes is the overall ageing of the global population. 2018 marked an important benchmark when the population aged 65 or above outnumbered children under five years. With the increase of life expectancy and falling fertility rates, the population is getting older worldwide and a greater number of developed countries are experiencing population reduction. Since 1990, the average life expectancy at birth for the world experienced a significant increase from 64.2 years in 1990 to current 72.6 years, and by 2050, it is likely to reach 77.1 years. The share of the population at age over 65 would increase from the current $9 \%$ to $16 \%$ by 2050 . These figures vary greatly from country to country and estimation for some parts of the world is even more dramatic. By 2050, in wealthiest parts of the world such as North America, Europe, Japan, South Korea, and others, over one-quarter of population are expected to be aged 65 or over. In global terms, the population aged 80 years or over is projected to triple by 2050 , rising from the current 143 million to 426 million.

At the same time, there is a clear trend of falling fertility rates worldwide. Since 1990, there has been a significant decline in fertility rates from 3.2 births per woman in 1990 to current 2.5. By 2050, this figure is expected to fall down to 2.2 , which is slightly above the rate at which the replacement population is ensured. Thus, low fertility rates have already caused $1 \%$ or higher population loss since 2010 in at least 27 countries.

However, one of the important factors determining global demography is the gap in many indicators that persist between most developed countries and the developing world. Although the rates of migration are expected to increase worldwide, the natural growth or decline of the population is expected to be the dominant factor in determining the global population distribution. Thus, according to the UN projection, nine countries will be responsible for more than half the projected growth of the global population from 2019 to 2050. These are India, Nigeria, Pakistan, the Democratic Republic of the Congo, Ethiopia, the United Republic of Tanzania, Indonesia, Egypt and the U.S. One of the most interesting benchmarks in this regard is that India is expected to become the most populated country overtaking China by 2027 . Thus, by 2050, the top ten countries in terms of their population size would be India (1,639 million), China (1,402 million), Nigeria (401 million), the U.S. (379 million), Pakistan (338 million), Indonesia (331), Brazil (229), Ethiopia (205 million), Democratic Republic of Congo (194) and Bangladesh (193 million). 
When it comes to Central Asia, in terms of many demographic parameters, the region is either close to the middle or a bit closer to more developed parts of the world in a global ranking. Between 1990 and 2019, the total population of Central Asia has grown by $46.1 \%$ from 50.1 million people to 73.2 million, which is almost the same as worldwide relative population growth. By 2050, the population of Central Asia is expected to grow by $36.9 \%$, which is faster than the world average of $26.2 \%$, crossing benchmark of 100 million people. Uzbekistan would remain the most populous state of the region with 42.9 million people, followed by Kazakhstan (24.0 million), Tajikistan (16.2 million), Kyrgyzstan (9.1 million) and Turkmenistan (7.9 million).

The UN population projections are highly important in terms of forecasting the socioeconomic development of a country and one of the most valuable parameters is the median age of the population, which is the boundary that divides a population into two numerically equal groups. Basically, lower median age implies a larger proportion of younger working age population and therefore is more favorable for economic growth. Consequently, the higher it gets the more difficult it becomes to stimulate economic growth. As we can see from Figure 1, the projected median age for Kazakhstan for 2020-2050 is between 31 and 34 years, which can be considered as favorable for the economy in general. Although it is, higher than the median age projection for entire Central Asia, it is lower than in other middle-income countries and the world average and it is way much lower than in high-income countries. It is interesting to note that throughout 2030-2040 the median age in Kazakhstan is expected to decline slightly, probably due to an expected increase in the number of births.

Figure 1. The median age of the population

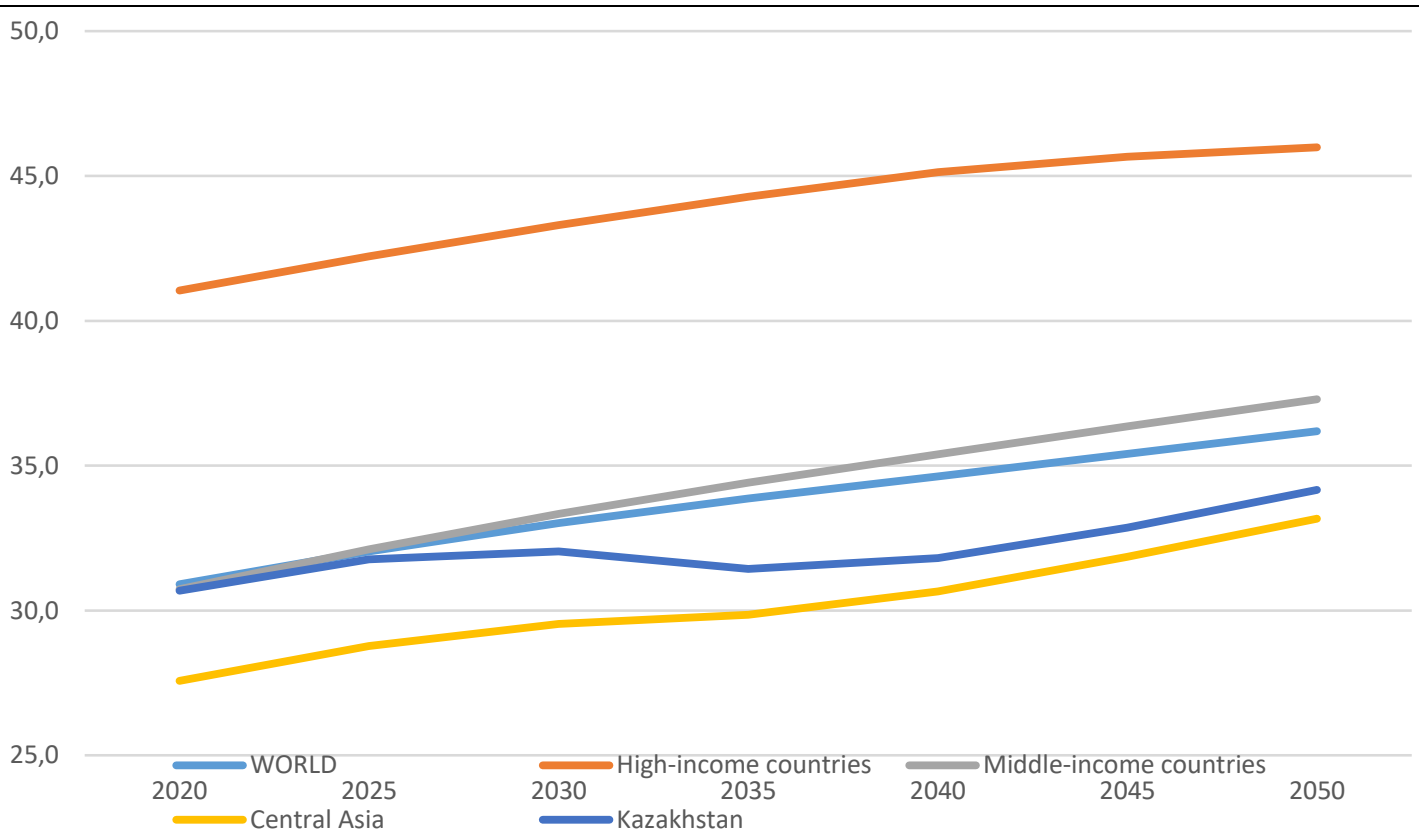

Source: UN World Population Prospects 2019

Another key important demographic parameter for forecasting economic development is the percentage of working age population, which is the percentage share of the population within the age group from 15 to 65 years out of the total population. It rather straightforward that high economic growth rates are more feasible in countries with larger shares of working age population. As we can see from Figure 2, the share of working population in Kazakhstan as well as in Central Asia, in general, is expected to increase during the period between 2025 and 2035, which is very different from the worldwide patterns. However, after 2035, this indicator is expected to start a gradual decline. 
Figure $2 . \%$ of working age population

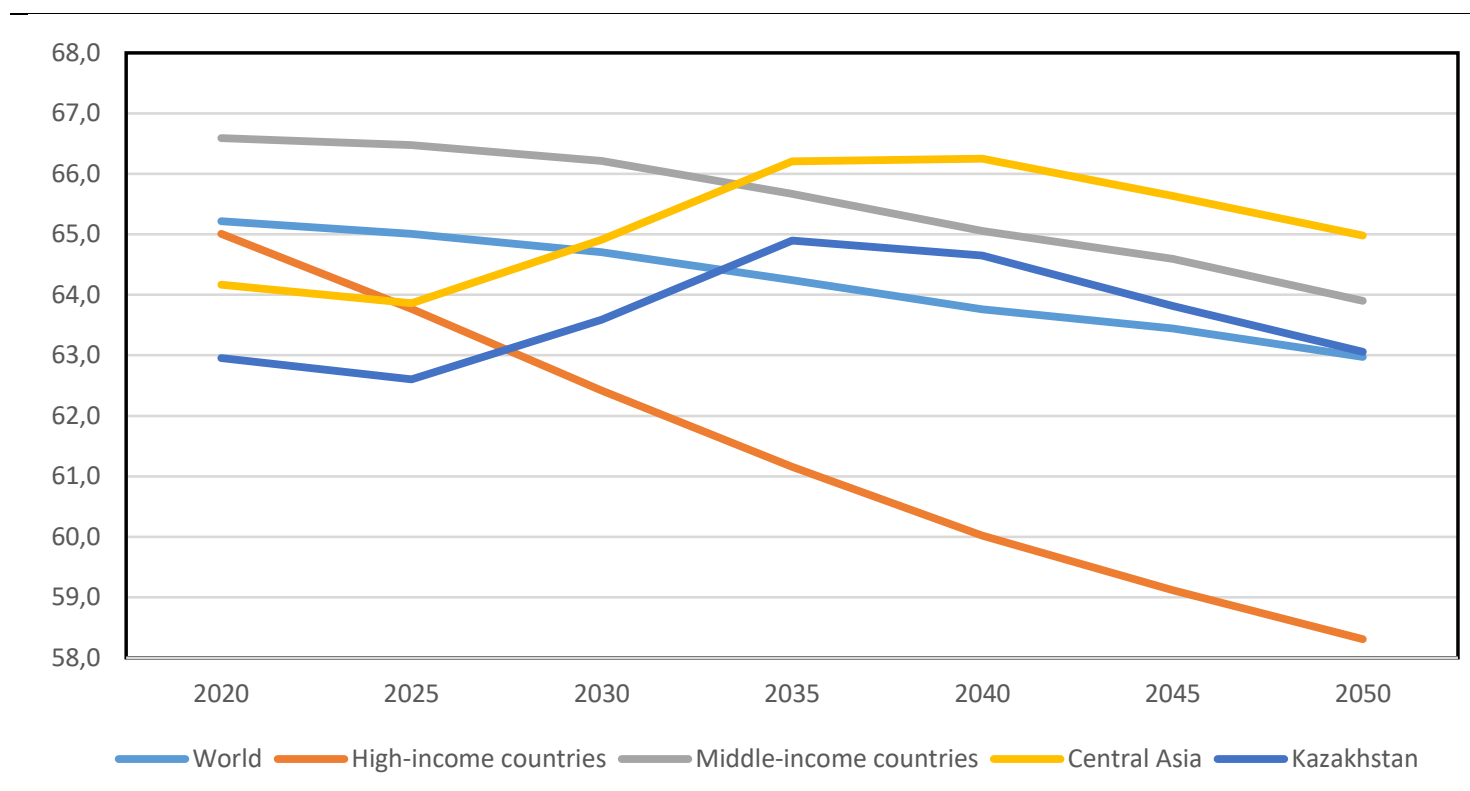

Source: UN World Population Prospects 2019

Another indicator that is used to predict economic sustainability and is directly related to previous ones is the dependency ratio, which is a measure of the number of dependents aged under 15 and over the age of 65 , compared with the total working-age population aged between 15 and 64. Hence, higher dependency ration makes the economy less responsive to simulative measures. We can see from Figure 3 that, according to the UN projections, during 2020-2025 the dependency ratios for Kazakhstan and Central Asia is higher than for the rest of the world including even high-income countries. However, after 2025 this indicator is expected to drop significantly remaining below the world average and at about the same level with other middleincome countries.

According to the Committee on Statistics of the Ministry of National Economy of Kazakhstan, in 2018, the GDP of the country grew by $4.1 \%$ reaching $\$ 172.9$ billion. According to the latest IMF World Economic Outlook, the world GDP is expected to grow by $3.6 \%$ in 2020. Based on UN demographic projections and assuming that the world GDP would grow at $3.6 \%$ yearly until 2050, we can obtain minimum real GDP growth necessary for Kazakhstan in order to maintain the same GDP per capita as it has currently. The estimates presented in Figure 4 show under conditions of UN demographic projections, Kazakhstan would need to maintain its yearly real GDP growth between $4.3 \%$ and $4.7 \%$ throughout $2020-2050$ in order to maintain its current level of welfare relative to the rest of the world. In other words, these growth rates would allow Kazakhstan to grow at 3.6\% yearly in absolute terms and at the same time, it would stay at the same level in terms of GDP per capita relative to the rest of the world. The gradual descent of the necessary growth rate is related to the fact that the population growth of Kazakhstan would gradually decelerate from current $1.2-1.3 \%$ to around $0.8 \%$ by the mid-21st century.

Figure 4. The minimum annual real GDP growth rate necessary for retaining the current economic position relative to the rest of the world for Kazakhstan 


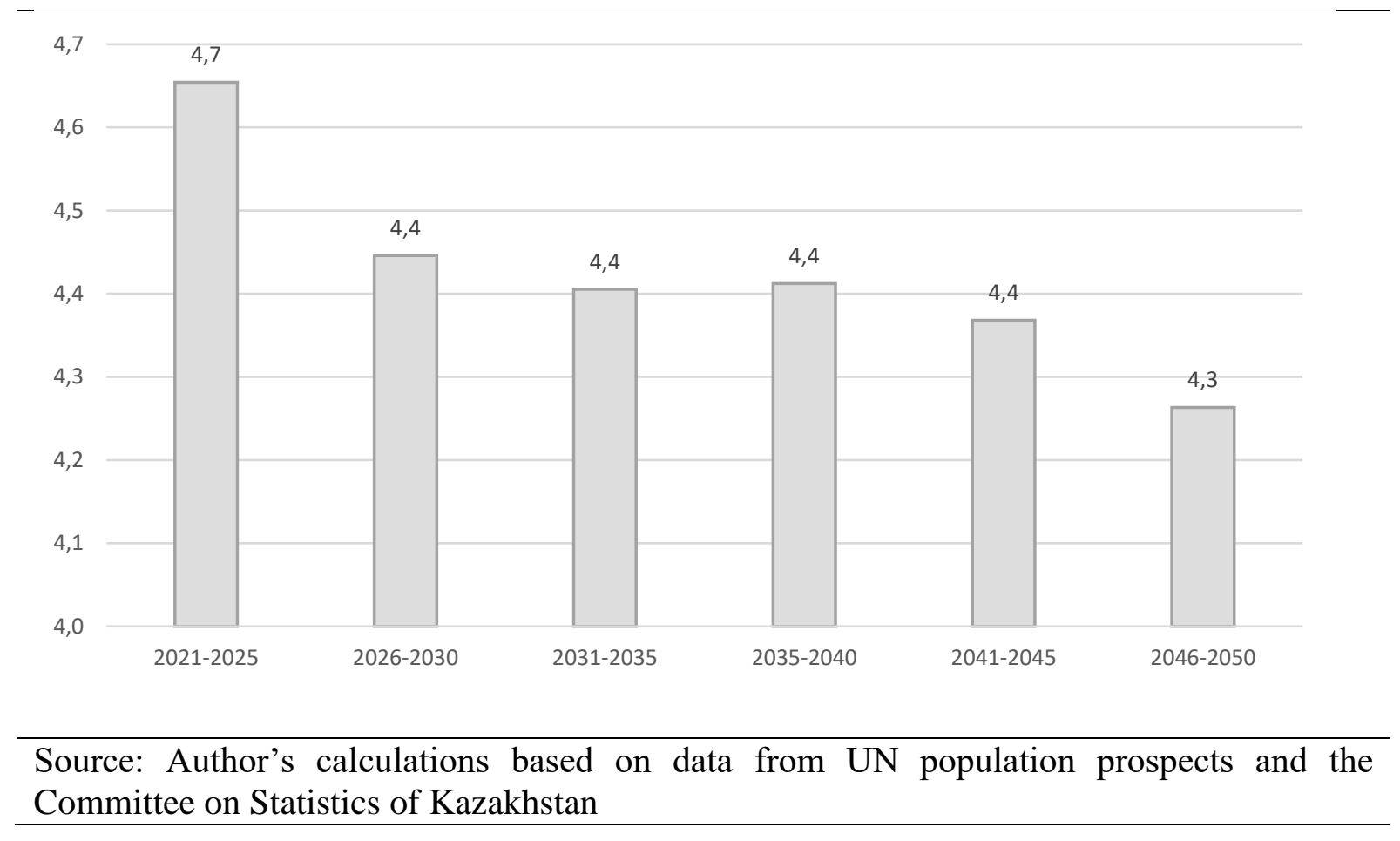

The UN Population Prospects 2019 show that the world's demographic picture in the $21 \mathrm{st}$ century will be shaped by current demographic trends such as declining birth rates, increasing life expectancies, demographic transition, migration, and others. As a result, there we can expect dramatic changes in the age structure of populations and the spatial distribution of the world's population. It is clear that these and other processes would generate serious economic challenges for most of the countries. Central Asia is one region that is expected to experience a faster relative population growth $(36.9 \%$, ) compared to the rest of the world on average $(26.0 \%$,) by the middle of the 21 st century. Analysis of some indicators highly important for the economic performance of a country shows that Kazakhstan, as well as the entire region of Central Asia, has a demographic profile that is very favorable for having economic growth within the next three decades. Factors like relatively faster population growth, younger median age, a larger share of working-age population and descending dependency ratio will provide significant opportunities for economic growth in Central Asian states. On the other hand, demographic growth at rates above the world average will require faster economic growth. Simple estimates based on the new demographic data show that for Kazakhstan it is necessary to maintain 4.3-4.7\% of annual real GDP growth in order to retain its current economic position relative to the rest of the world.

\section{References:}

1. Committee on Statistics of the Ministry of National Economy of Kazakhstan (2019). Integrated accounts. Retrieved from http://old.stat.gov.kz/faces/wcnav_ externalId/home National Account

Integrated?_afrLoop=12667865384117604\#\%40\%3F_afrLoop\%3D12667865384117604\%26_a df.ctrl-state\%3D7gylf90x1_34. Accessed on 24.01.2020.

2. Committee on Statistics of the Ministry of National Economy of Kazakhstan (2019). Population. Retrieved from http://old.stat.gov.kz/faces/wcnav_externalId/ home_Numbers Population?_ afrLoop $=12667999701153268$

\#\%40\%3F_afrLoop\%3D12667999701153268\%26_adf.ctrl-state\%3D7gylf90x1_51. Accessed on 24.01.2020.

3. UN World Population Prospects (2019): Retrieved from https://population.un.org/ wpp/Publications /Files/WPP2019_Highlights.pdf. Accessed on 24.01.2020. 
4. World Economic Outlook Update, January 2019 (2019): Retrieved from https://www.imf.org/en /Publications/WEO/Issues/2019/01/11/weo-update-january-2019. Accessed on 24.01.2020.

\section{Пайдаланылған әдебиеттер тізімі:}

1. Қазақстан Республикасы Ұлттық экономика министрлігінің Статистика комитеті (2019). Біріктірілген шоттар. Алынған http://old.stat.gov.kz/faces/wcnav_ сыртқы / ішкі ұлттық шот біріктірілген бе?_afrLoop=12667865384117604\#\%40\%3F_afrLoop\%3D12667865384117604\%26_adf.ctrlstate\%3D7gylf90x__34. Өтініш берген күні: 24.01.2020.

2. Қазақстан Республикасы Ұлттық экономика министрлігінің Статистика комитеті (2019). Халық саны. Алынған http://old.stat.gov.kz/faces/wcnav_externalld / халықтың үй нөмірлері?_ afrLoop=12667999701153268 \#\%40\%3F_afrLoop\%3D12667999701153268\%26_adf.ctrlstate\%3D7gylf90x1_51. Өтініш берген күні: 24.01.2020.

3. БҰҰ-ның әлемдік популяциясының перспективалары (2019): алынған https://population.un.org/ wpp / Жарияланымдар / файлдар /WPP2019_Highlights.pdf. Өтініш берген күні: 24.01.2020.

4. Әлемдік экономика болжамын жаңарту, қаңтар 2019 (2019): алынған https://www.imf.org/en / Жарияланымдар / WEO / сұрақтар/2019/01/11/шео-жаңарту-қаңтар-2019. Өтініш берген күні: 24.01.2020. 